\title{
"Words of mass destruction": British newspaper coverage of the genetically modified food debate, expert and non-expert reactions
}

\author{
Guy Cook, Peter T. Robbins and Elisa Pieri
}

This article reports the findings of a one-year project examining British press coverage of the genetically modified (GM) food debate during the first half of 2003, and both expert and non-expert reactions to that coverage. Two proGM newspapers and two anti-GM newspapers were selected for analysis, and all articles mentioning GM during the period in question were stored in a machine readable database. This was then analyzed using corpus linguistic and discourse analytic techniques to reveal recurrent wording, themes and content. This text analysis was complemented by 12 interviews with experts involved in the communication of GM issues, and 12 focus-group sessions in which members of the public reacted to selected newspaper texts and other GM material. Both in the press and in public reaction, the issue of GM was found to be intimately associated with other political events of the time, notably the invasion of Iraq. Except among experts, there was little awareness of the official national debate and issues were approached in more general terms. Pro-GM characterization of the issues as primarily scientific, both by newspapers and experts, was rejected by the anti-GM press and campaigners, and by the focus-group participants. They assessed the issues in a more global frame, rejecting scientists and companies as unreliable. In addition, they linked both US and British GM policy to the invasion of Iraq, and, by analogy, rejected pro-GM arguments as untrustworthy.

\section{Introduction}

As all players increasingly realize, linguistic choices and framing devices are likely to prove crucial in promoting the introduction of genetically modified (GM) technology (AEBC, 2001: 15). A growing number of surveys have explored public attitudes to biotechnology in Europe (BEPCAG, 1997; Davidson et al., 1997; Scott et al., 1999; Burton et al., 2001; Gaskell and Bauer, 2001; Marris et al., 2001; INRA, 2002; Pardo et al., 2002; Heller, 2003), yet the link between the language and the social construction of the debate has received comparatively little attention. In an attempt to augment understanding of this aspect of the debate, this article reports the results of a one-year research project ${ }^{1}$ which examined the language used in British press coverage of the GM food debate and public reactions to it.

In Britain, the year 2003 saw increased controversy over GM. Public and academic interest reopened and intensified under the influence of a variety of events. These included: 
meetings and consultations ${ }^{2}$ aimed at "the general public"; the government sponsored GM Nation? debate and its subsequent report (Heller, 2003); the results of the field trials of three GM crops ${ }^{3}$ reports by the government strategy unit ${ }^{4}$ and GM science review panel $;{ }^{5}$ and persistent rumors (which materialized in 2004) that the government was about to allow commercial cultivation of at least one GM crop. Meanwhile, internationally, interest intensified due to a number of factors: rapidly increasing GM crop production worldwide; continuing arguments from the biotechnology industry about future "nutraceutical" health benefits; the impact of claims about the potential alleviation of third-world malnutrition (Pinstrup-Anderson and Schioler, 2001); the divergence of US and European policy (Hornig Priest, 2001; Wield and Carr, 2002); and the growth of opposition to GM food in North America (Smith, 2003).

In contrast to this wider international backdrop, in Britain the phrase "the GM debate," which we had chosen in the title of our application for funding, proved in 2003 to be an ambiguous term, capable of both narrow and broad interpretations. It was taken sometimes to refer to the official government sponsored GM Nation? public consultation, sometimes to the larger official National Debate of which GM Nation? was only one strand (the others being scientific and economic enquiries and reports), and sometimes much more generally to any discussion or dispute over GM. Our interviewees, who all had professional interest in GM, generally took the phrase to refer to the official National Debate, while the members of the public in our focus groups seemed largely unaware that this debate was taking place at all. This in itself seemed to reveal a lack of communication between key players and public, with the former having a much more insular view than the latter, and apparently regarding their own activity as more significant and influential than it actually was. We have followed the public lead, using the term "GM debate," unless otherwise specified, to mean general discussion in a variety of fora, including but not limited to the official British National Debate.

There was in addition a new dimension to discussions of GM in Britain which had not been present in the debate prior to 2001, and gained extra intensity with the events of 2003 . This was the overweening preoccupation of the media with the "war on terror" (from 2001) and then with the war in Iraq (before and during the US-led invasion of March 2003). On the one hand, these media preoccupations displaced GM as a major news story. On the other hand, they provided a rich source of metaphor, allusion and comparison for commentators. Campaigns for or against GM were compared to invasions and battles, and their proponents to terrorists or defenders of freedom, depending on the point of view. At the same time, more literally, the GM issue was seen by many as one component in US global strategy. The US dispute with the European Union (EU) over GM mirrored that with France and Germany over Iraq, with the British government taking a pro-US stance on both issues.

\section{Aims, objectives and data}

There was thus a wealth of material for research into the language choices and communicative strategies of those involved with GM, their impact upon public trust and understanding, and the scientific, ethical, political and social issues which surround the communication of controversial new technology in general (Scott, 2001). The general aim of our research was to produce a qualitative discourse analysis of reports and discussion of GM issues in Britain during the first half of 2003, and by this to contribute to understanding of how new technology is communicated to the public and assessed by them. Specific objectives were to document and analyze: 
- the ways in which GM food technology was presented in the British press during the first half of 2003;

- the views of stakeholders about public knowledge and opinions of GM;

- the effect on public opinion of the language used in press coverage of GM.

To achieve these objectives, we collected three datasets, as follows:

1. press reports, articles and letters published during January-July 2003;

2. transcriptions of 12 interviews with representatives and text producers from stakeholder organizations;

3. transcriptions of 12 focus-group sessions.

Below we discuss and analyze each of these datasets in turn. Before we do, it is apposite to say something about our research methods and why they are distinctive.

\section{Methodology}

Our discourse analysis of the GM debate combines perspectives from both sociology and linguistics. As in both disciplines, we interpret the term "discourse" to mean the interaction between the macro-level of social frame and the micro-level of linguistic choices, but the methodology we employ draws upon two different approaches to this relationship, one from cultural sociology and the other from functional and applied linguistics. ${ }^{6}$

In cultural sociology, discourse analysts approach texts from the standpoint that language is not "simply a means of reflecting or describing the world, and a conviction of the central importance of discourse in constructing social life" (Gill, 2000: 172). Underlying this is the view that reality is the product of contests over meaning between actors (Berger and Luckmann, 1967). The aim is to uncover how different agents frame arguments, the processes by which arguments are contested in public space (e.g. the media), and ways in which this contributes to a social shaping of reality (Gamson and Modigliani, 1989; Robbins, 2003). Thus, for cultural sociologists, the main concern is analyzing how issues become socially manufactured, and this benefits from an analysis of the language used in the different framings of the matters at stake. ${ }^{7}$

Applied linguistics discourse analysis on the other hand focuses primarily upon the micro-level of linguistic choices as a reflection of their social purposes and effects. The central tenet of this approach (by no means incompatible with that of cultural sociology) is that the coherence and meaning of the language used in a text cannot be analyzed or accounted for separately from the social context of its production and reception, the intentions of the sender, and the knowledge and attitudes of the receiver (Brown and Yule, 1983; Stubbs, 1983). In recent years, however, the practice of this type of discourse analysis has been vulnerable to two criticisms. The first (e.g. Stubbs, 1996) is that it focuses too closely upon arbitrarily selected single texts rather than seeking to establish the frequency and typicality of linguistic features by systematically comparing many texts. The second (e.g. Gee, 1999) is that it relies too much upon the analyst's own intuitions to establish the author's intentions or effects on readers. In line with current developments, our investigation compensated for the first of these shortcomings by using corpus linguistic analysis, and for the second by investigating participant intentions and responses through interviews and focus groups. We shall now say something about each of these in turn.

Corpus linguistic analysis uses automated searches of large electronically stored databases of actual language use (whether texts or transcripts) to identify recurring linguistic patterns. It can establish, for example, which words are particularly frequent in a given 
database (and whether they occur more or less frequently than in another specialized or general database), which words commonly occur together, and whether they associate with negative or positive contexts (Louw, 1993; Hunston, 2002; Stubbs, 1996). All of this allows the analyst to identify language use which might have eluded, or even been denied by, intuition.

A variety of software programs ${ }^{8}$ enable researchers to build and analyze their own corpora, and to compare them with larger corpora such as the British National Corpus of 100 million words. One revealing and particularly useful output from such programs is the concordance, centering occurrences of a particular word in such a way that the linguistic contexts in which it occurred are revealed. Table 1 (from our own newspaper corpus) shows actual uses of the word "Frankenstein," demonstrating that, contrary to our expectation, the phrase "Frankenstein food" is used more often by proponents of GM to characterize the opposition ("so-called Frankenstein foods," "lurid warnings about Frankenstein foods") than by the opposition itself.

Corpus software enabled us to analyze our three datasets not only separately, but also comparatively, contrasting the language used in press reports, interviews and focus groups. Thus, for example, we can compare use of the word "Frankenstein" in our newspaper corpus with its use by focus-group participants, who chose it much less frequently, in fact only twice.

In addition to corpus linguistic analysis, our data were also coded manually for recurrent topics, allowing us to collate and cross-reference for content analysis. ${ }^{9}$

Corpus analysis, however, is mechanical. It tells us about behavior on a large scalewhat was said or written-but not about how that behavior was meant or interpreted in context by the people involved. To refine the results we obtained from the corpus analysis therefore, we conducted 12 interviews with people involved in communicating views about GM, asking them about their communication strategies. We also conducted 12 focus-group sessions with members of the public, presenting them with extracts from our newspaper corpus and other sources, to discover how they reacted to communications about GM.

Focus-group research does not aim for a representative sample of the population, but rather to generate talk that will extend understanding of an issue. Groups are defined as a "theoretical sample" consistent with the constant comparative method (Glaser and Strauss, 1967; Becker, 1998). In accordance with these principles, it is necessarily smaller in scale

Table 1. A concordance of the work "Frankenstein" in the newspaper corpus

\begin{tabular}{ll}
\hline ncern and protests across Europe about & "Frankenstein food". Monsanto retr \\
acting as cheerleaders' for so-called & Frankenstein foods. It is said to \\
ucrats alone. Lurid warnings about & "Frankenstein foods" have bedevilled the \\
taken seriously. Fed a steady diet of & Frankenstein food stories and still \\
reel eating the food. All this talk of & Frankenstein food is misleading. \\
not. GM products have been dubbed & Frankenstein foods over fears they coul \\
te more known for hysterical panic over & "Frankenstein food". This report is p \\
pped questioning the safety of socalled & Frankenstein food. His research an \\
$\begin{array}{l}\text { However, the fight against so-called } \\
\text { sion on the cultivation of so-called }\end{array}$ & Frankenstein foods will suffer a blow \\
fearful about the safety of so-called & "Frankenstein foods" would be made in Br \\
engineering practices and ehr & Frankenstein foods. The administratio \\
after all these $*$ What with & Frankenstein and things like this \\
\hline
\end{tabular}

The program Wordsmith Tools automatically searches the corpus and centers the word, showing a specified amount of the context in which each use occurred. 
than corpus analysis, which can survey large quantities of language used by large numbers of people. However, it brings greater depth, enriching the more sweeping but less sensitive findings of corpus analysis.

Our discourse analysis was therefore eclectic, bringing together cultural sociological and applied linguistics traditions, as well as elements of grounded theory (Strauss and Corbin, 1990) and critical discourse analysis (Fairclough and Wodak, 1997). As qualitative discourse analysis, our work relied largely upon close reading of the whole dataset, complemented by more intensive examination of selected passages. We supplemented this critical reading with automated techniques which allowed for the rapid identification and cross referencing of recurrent themes, topics, collocations and words, thus ensuring an awareness of the overall profile of the data, and providing an objective counterbalance to the inevitably partial nature of selective analysis. At the same time we were careful to keep corpus analysis in perspective, ${ }^{10}$ seeing this mechanical process as contributing to, rather than determining, findings, and we have aimed to be "corpus-informed" rather than "corpusdriven." In practice, in other words, our intimate knowledge of the data allowed us to take potentially distorting factors into account in order to enrich the interpretation suggested by the automatic output, and test it in new directions rather than stopping with that layer of analysis. Lastly, and perhaps most importantly, we supplemented both our own reading and corpus analyses by eliciting commentary from both text producers and text receivers. All of these approaches constantly complemented and informed each other. Thus our choice of typical newspaper texts to show to the focus groups was informed by our linguistic and content analysis of the newspaper corpus, and conversely our analysis of the corpus was extended in new directions by focus-group commentary on particular word choice and phrasing, and which language choices participants noticed.

We now turn to more details of the databases and our findings, focusing mainly upon the newspaper corpus and the focus-group reactions to examples of newspaper articles.

\section{Databases and findings}

\section{The newspapers}

Our press corpus was drawn from four British newspapers, the Daily Mail, the Guardian, the Sun, and The Times during the period January-July 2003. Every article that mentioned GM was identified and downloaded ${ }^{11}$ into an electronic database. We chose these particular newspapers for their different views, styles and readerships (Jucker, 1992). They were also selected on the premise that the tabloid Sun and broadsheet-style The Times were the most pro-GM British newspapers, while the tabloid-style Daily Mail and the broadsheet Guardian seemed to be the most anti-GM. ${ }^{12}$ We thus had one tabloid-style and one broadsheet-style newspaper on each side. All in all we collected 446 reports, articles and letters: 210 from the Guardian, 82 from the Daily Mail, 142 from The Times, and 12 from the Sun (the small number reflecting its comparative lack of interest in "serious" news). Even though the resulting corpus was large (over 259,000 words), it was still possible to study it and gather additional insights through close reading.

In general, the four newspapers analyzed held consistently to either a pro-GM stance (The Times and Sun) or an anti-GM stance (Guardian and Daily Mail). This is reflected in their choice of writers and sources, in their selection and presentation of stories, and in the language used. Table 2 summarizes the newspaper coverage between January and July 2003, focusing on articles that had a clear pro- or anti-GM slant identified with reference to language use, the evidence used, the affiliations of commentators, and how GM was 
Table 2. Newspapers, key contributors, and numbers of pro- and anti-GM articles published January to July 2003

\begin{tabular}{|c|c|c|c|c|c|c|c|c|}
\hline \multirow{2}{*}{$\begin{array}{l}\text { Newspaper } \\
\text { Article perspective }\end{array}$} & \multicolumn{2}{|c|}{ Daily Mail } & \multicolumn{2}{|l|}{ Sun } & \multicolumn{2}{|l|}{ Guardian } & \multicolumn{2}{|l|}{ Times } \\
\hline & Pro-GM & Anti-GM & Pro-GM & Anti-GM & Pro-GM & Anti-GM & Pro-GM & Anti-GM \\
\hline January & 0 & 7 & 2 & 0 & 1 & 11 & 3 & 1 \\
\hline February & 2 & 1 & 0 & 0 & 2 & 9 & 3 & 5 \\
\hline March & 1 & 3 & 1 & 0 & 1 & 8 & 1 & 1 \\
\hline April & 3 & 7 & 1 & 0 & 4 & 10 & 0 & 3 \\
\hline May & 0 & 5 & 0 & 1 & 3 & 23 & 2 & 5 \\
\hline June & 1 & 14 & 1 & 0 & 7 & 35 & 15 & 8 \\
\hline July & 0 & 18 & 0 & 0 & 4 & 22 & 11 & 6 \\
\hline
\end{tabular}

discussed in the narrative. In all cases, except for the Sun, numbers of articles on GM increased in June and July as the National Debate approached its conclusion.

In most cases, stories on GM functional foods directed at first-world markets, such as allergen-free peanuts and seafood, and caffeine-free coffee plants, were covered positively, regardless of the newspaper. Thus even in the generally anti-GM Daily Mail we find stories such as the following:

\section{Text 1}

THE threat of peanut allergies could soon be wiped out by genetic engineering, scientists have revealed.

In laboratory tests, they have succeeded in altering the makeup of the peanut so it no longer triggers a life-threatening reaction.

The safe peanuts are part of a new generation of allergy-free food being produced by several international scientific teams. Others being developed include seafood and soya beans engineered to be less of a risk. In Britain, the number of children developing potentially fatal allergies to nuts has trebled in the last decade. (Daily Mail, 17 February 2003)

Conversely, stories on foods directed at third-world markets, such as golden rice and GM potatoes, as well as conventional GM crops such as soya, maize and wheat, were framed consistently with the general stance of the newspaper. Thus a report in the Guardian on the advent of GM cotton to India included:

Text 2

About 55,000 farmers across seven states, roughly 2 percent of India's cotton growers, sowed the genetically engineered Bollgard cotton seed, which Monsanto describes as resistant to one of the most formidable cotton pests, the bollworm. But anxiety about long-term effects of using modified seed-the fear of "Frankencrops"-and concern among nationalists, who worry that Indian farmers could find themselves tied to Western companies, have slowed India's march toward biotech farming. (Guardian, 8 May 2003)

Both of these texts (1 and 2) exemplify certain features that we found to be widespread in all four newspapers. Firstly, they report possible rather than actual developments-a slant revealed by the use of modal verbs ("peanut allergies could soon be wiped out" rather than "peanut allergies have been wiped out"), a distinction which might be easily missed in a casual perusal of the kind that may be typical of newspaper reading (O'Halloran, 2003). 
Secondly, they cite sources and authorities which may-assuming readers of a particular newspaper also share political allegiances-indirectly guide readers to an assessment of the argument. These sources were often cited through add-on phrases such as "which Monsanto describes as," "concern among nationalists," "scientists have revealed." Thirdly, they state facts, typically in final position, without making the connection to preceding text explicit, thus leaving relevance to be inferred: "In Britain, the number of children developing potentially fatal allergies to nuts has trebled in the last decade." We shall encounter all of these textual features again in further examples below. They illustrate, from among the many features that we analyzed in the course of our project, three different aspects of language use. One (modal auxiliary verbs) is primarily syntactic, one (naming a source and using reported speech) primarily semantic, and one (leaving readers to infer connections) primarily pragmatic. ${ }^{13}$

The broadsheet newspapers tended to adopt a particular angle on GM, reporting the opposing view in published letters to the editor, rather than in full-length articles. In general, the arguments in pro-GM stories in The Times were rooted in a "deficit model" of the public understanding of science: the idea that opposition to the technology is due to a lack of scientific understanding (Gregory and Miller, 1998: 89-90). They focus on the "scientific fact" of GM safety, characterizing the opposition as ignorant and fearful, while calling for "calm" and "reasoned" debate. ${ }^{14}$ Many articles discussed the issues in a narrow frame as a purely technological issue divorced from a wider historical, political and cultural context. Anti-GM articles in the Guardian on the other hand emphasized the social and political context of GM knowledge or practices, the economic interests of those who fund or support it, and the likely effects of technology adoption.

The tabloid newspaper the Sun carried very few articles on GM, and those that were covered examined issues that most papers addressed favorably, such as medical biotechnology. More than in the other three newspapers, the GM issue was forced out by coverage of Iraq. (Coverage was reduced to only one article per month in the period February-April 2003.) Nevertheless, GM became coupled with other issues in interesting ways. The following article manages to bring together the claimed medical benefits of a GM product with the fight against terrorism (the poison ricin had been linked to an alleged al-Qaeda plot to poison the London water supply two months earlier).

Text 3

\section{RICIN POISON “KILLS CANCER”}

SCIENTISTS have turned the deadly poison ricin into an anti-cancer drug. The toxin, discovered this year in the hands of suspected terrorists, has been used as an experimental treatment of patients with lymphoma, a cancer of the blood.

Experts in Texas genetically modified ricin and found it killed off tumour cells in mice.

Potentially lethal side effects were cut fivefold.

Doctors who used ricin in tests on lymphoma patients believe it could help develop new drugs known as magic bullets.

A hoard of ricin, extracted from castor beans, was found in London in January. (Sun, 10 March 2003)

Note here the contradiction between the certainty of the opening construction "Scientists have turned the deadly poison ricin into an anti-cancer drug," presented as an established 
fact, and the subsequent modal construction ("could help develop new drugs"), acknowledging that this development is by no means certain at all. This framing of yet unrealized and only potential future applications as established facts and certain trajectories of development contributes to a sociology of expectations (Hedgecoe, 2004), where present risks and benefits are weighed and traded off against strong assumptions of what could and is - to a greater or lesser degree-likely to be achieved. The immateriality of these promises is obscured by this framing of events, so that the expectations and promises are perceived as very real, which, in turn, means they can end up playing a central role in the decisionmaking processes.

The same theme of GM as an ally in the fight against terror is present in the following extract from The Times:

Text 4

\section{PLANTS MAY WARN OF BIO-TERROR}

American scientists are developing a genetically modified plant that would change colour when exposed to biological or chemical weapons.

Researchers at Colorado State University have won a grant of nearly $£ 300,000$ from the US Department of Defence to investigate if it is possible to produce "plant sentries" for malls and offices to provide early warning of a bio-terrorist attack. (The Times, 15 February 2003)

Again we find a modal verb indicating that we are dealing with hypothetical rather than actual events ("plants may warn," "plant that would change colour"). Both articles make frequent reference to sources and authorities, though these are rather vaguer in the Sun ("scientists," "experts," "doctors") than in The Times ("American scientists," "Researchers at Colorado State University," "the US Department of Defence"). In the Sun article, we also have an apparently disconnected factual statement at the end leaving readers to infer a connection: "A hoard of ricin, extracted from castor beans, was found in London in January."

Both uses of authorities, and reliance on reader inference can be used to considerable effect. Anti-GM articles in the Daily Mail rely almost entirely on Members of Parliament and anti-GM groups for quotations. At times, an apparently pro-GM report is turned against itself through implicature as the source is named.

\section{Text 5}

GENETICALLY modified crops could help endangered birds such as lapwings and skylarks thrive again in Britain, says a study. It follows the development of herbicide resistant GM crops and a herbicide which can kill weeds much later in the year.

In trials there was a sharp rise in weeds, seeds and insects through the late spring and early summer, providing nesting sites and a crucial food source for chicks.

The study was funded by GM giant Monsanto. (Daily Mail, 15 January 2003)

or

\section{Text 6}

Tony Blair has suggested that opposition to GM is emotional and irrational, even though respected scientists have raised questions on health and the environment.

Science Minister Lord Sainsbury is believed to be behind Mr Blair's positive view of GM on the basis that it will give Britain the lead in the science world and create jobs. 
The supermarket multimillionaire, a substantial Labour donor, has substantial financial interests in biotech firms through a blind investment trust.

He has pledged to leave the room whenever GM and biotech issues are discussed by cabinet and departmental committees. (Daily Mail, 17 February 2003)

Analysis of general language corpora reveals that the phrase "to be behind someone/ something" has what corpus linguists refer to as a negative semantic prosody (Louw, 1993). That is to say it is much more commonly linked with something bad than something good. Allusion to sources as a way of undermining credibility is common on both sides. Favorites for the anti-GM press are Tony Blair and Lord Sainsbury, whose respective links with the United States and major biotechnology companies were constant themes in the Daily Mail throughout June when the paper adopted a "Daily Mail Campaign/Frankenstein Food Watch." For the pro-GM side the bogeyman is Michael Meacher, the leading opponent of GM in Britain (who resigned in 2003 from his post as Environment Minister in the Blair government). His surname appeared no fewer than 189 times in our newspaper corpus making it the most frequent proper noun, ahead of "Bush" (154 times), "Blair" (147 times), "Monsanto" (113 times), and "Sainsbury" (the man not the British supermarket chain, 123 times). He is "Meacher the preacher," "Meacher blight," the leader of "the Meacherites" (The Times, 17 February 2003), who contradicts experts and scientists, and who "blasts" rather than speaks.

Text 7

"SAFE TO EAT GM"

EXPERTS last night said there was no scientific evidence to support a ban on genetically-modified crops and foods. The GM Science Review Panel claimed there had been no proven ill effects in seven years of humans eating GM ingredients.

The scientists warned that safety regulations needed to keep pace with the latest developments.

But former Environment Minister Michael Meacher said GM food COULD have serious consequences for health.

He blasted: "What is a public scandal is that no one has actually looked for the evidence of a health risk." (Sun, 22 July 2003)

Ironically, considering its own predilection for modals elsewhere, the Sun's upper-case emphasis of the modal verb "could" implies criticism of Meacher for dwelling on hypotheses rather than facts-confirming that its journalists are consciously aware of the significance of this form.

\section{Emotive epithets}

Both sides are given to hyperbolic and emotional epithets when describing the other. ProGM newspaper rhetoric (whether emanating directly from the writer or quoted from other sources) characterizes opposition as "scaremongering," "hostile," "irrational," "lurid," "feverish," "evangelical," "immoral," "unscientific," "ignorant," "emotional" and "antiscience," driven by "hysteria" and "panic." Verbs carry this condemnation as well as adjectives and nouns. Opponents are more frequently described as "worrying," "feeling" and "fearing," rather than "thinking"-which is what "scientists" and "experts" do. Paradoxically this is even the case in the anti-GM press as in text 2 above: "But anxiety about 
long-term effects of using modified seed-the fear of "Frankencrops"- and concern among nationalists, who worry that Indian farmers . . . ." In short, opposition is caricatured in a way which is most concisely summed up by the word "Luddite"15 - a label which, even when the word itself is not used explicitly, is frequently implied. As the official report on the British GM Nation? debate put it:

they [people in favor of GM] directly attack opponents' concepts of caution, which (they say) would have prevented almost any advance in technology, including agriculture itself. The word Luddite is often used. (Heller, 2003: para 63)

The report further argues that "opposition to the concept of precaution/Luddism" was one of the "predominant themes" of letters and e-mails in support of GM (Heller, 2003: para 102). The former US Secretary of Agriculture Dan Glickman, who became openly disenchanted with the Clinton administration's pro-GM policies, summed up the use of the word as follows:

What I saw generically on the pro-biotech side was the attitude that technology was good, and that it was almost immoral to say that it wasn't good, because it was going to solve the problems of the human race and feed the hungry and clothe the naked. . . And there was a lot of money that had been invested in this, and if you're against it, you're Luddites, you're stupid. That frankly was the side our government was on. (quoted in Lambrecht, 2001: 139)

\section{Metaphors}

Images of food and agriculture are resonant with symbolic meaning and lend themselves readily to metaphors. The press reports made frequent use of metaphors, with certain metaphor clusters (Lakoff and Johnson, 1980) particularly evident. For example, the debate was frequently described, by both proponents and opponents, as a "war," disagreements as "battles," and particular moves (speeches, articles etc.) as "attacks." Thus anti-GM campaigner George Monbiot writes of "the covert biotech war" and how "the battle to put a corporate GM padlock on our foodchain is being fought on the net." 16 Michael Meacher is quoted as saying "the GM food lobby had already won its battle in America." ${ }^{17}$ Headlines refer to the "BATTLE OF THE FOOD CHAIN"18 and "BLAIR LOSES GM BATTLE,"19 while in newspapers on both sides the dispute between the US and EU is frequently described in terms such as

The battle over GM crops ... GM foods in first assault of EU trade battle . . . The US led 12 countries into a battle in the World Trade Organisation . . . America is determined to win a wider trade battle over agriculture. (The Times, 14 May 2003)

this epic battle for food dominance. (Guardian, 17 May 2003)

The word "attack" is ambivalent. Sometimes it refers to verbal attacks made by one side or the other. Elsewhere they are physical attacks on crops, either by pests and weeds, or by demonstrators taking direct action. "Invaders" too may be either people or plants. Both GM crops themselves and protestors against them were described with this word. GM crops are described by the opposition as giving rise to "invasive superweeds," ${ }^{20}$ while on the pro-GM side they are described - using the emotive and nationalist "our" — as "unlikely to invade our countryside." "21 Protests are also frequently described as "invasions": "the invasion of the field by anti-GM demonstrators," 22 "Greenpeace's invasion" 23 etc. All of this was at a time when the news was full of literal invasion, battles and attacks. A further metaphor cluster 
centers around images of escape, impurity, and contamination. This at a time when another (perennial) preoccupation of the British press was immigration, asylum seeking, and the nature of British citizenship.

On occasion too, both GM plants and anti-GM protestors were explicitly described as terrorists. The coinage "bioterrorism" is used in a rather different way by both sides to refer to the other. Thus a letter to The Times observes that "The main hazard that GM crops present is that they attract crop-destroying attention-seeking bio-terrorists" (The Times, 6 June 2003), while on the other side Rama Lakshmi, writing of reaction to GM in India, observes that

However, opponents claimed that the environmental impact of genetically modified crops amounted to "bioterrorism." Ecologists said altered genes may enter the food chain, as many Indian villagers use cottonseed oil in their cooking. (Guardian, 8 May 2003)

The best way it seems, in the era of "the war on terrorism," is to try to identify your opponents as part of the enemy.

All these comparisons helped to conflate the GM issue with other current political concerns of the British press in 2003, specifically Iraq ("war"), mass migration ("invasion," "contamination" etc.) and terrorism-points which we shall return to in our analysis of the focus-group data and in our conclusion below.

We should not perhaps be too surprised by these connections. Debates over science and technology have a tendency to draw upon the issues of their time. Analyzing the powerful auditory image in the title of Rachel Carson's influential book Silent Spring (1962), Nerlich (2003) argues that, although it does refer to a literal truth (chemicals in farming do reduce bird populations and thus bird song) it also linked with other developments of that period, such as "the atomic bomb, the cold war, the space race," and in particular fears of the aftermath of nuclear war. The important point is not whether the prediction of a silent spring is factually accurate but that this particular choice galvanized opposition by drawing upon current political concerns. Such conceptual clusterings can be found in different epochs, and are analogous to framing devices, in the sense that they tap into wider cultural themes in society. If we move forward from the 1960s to the 1980s we find that descriptions of AIDS were conceived in terms of other preoccupations of the period such as political subversion and infiltration, and racial and sexual difference (Sontag, 1988). GM food, in the same way, drew to itself fears present at the time of our study (Finucane, 2002).

In our newspaper corpus, however, the invocation of war, territory and invasion was not entirely metaphorical. For both opponents and proponents, GM food, Iraq and terrorism often seemed to be connected. An obvious reason is that discussion of all three tends to center upon US policy. Both GM food and Iraq were in 2003 the occasion for bitter disagreements between the US and Europe, and both gave rise to concern about US motives. Opponents of US policy in the Gulf saw the campaign as an attempt to control oil supplies; those against GM food saw its development as an attempt to control the world's food supply. The report on the government-funded GM Nation? debate in Britain notes that:

Comments on the debate were often coloured by suspicion over the motives for holding it. People attacked the debate as "window-dressing", cover for a decision already made. This was often compared to the government's attitudes to protests against the Iraq war. (Heller, 2003: para 72)

And in the press of the time we find frequent parallels drawn: 
GM food: This is much worse than the intercontinental split over Iraq, if measured by the distance between the two views. At least, in the case of Saddam Hussein, both Europe and the US agreed that he was a bad guy. There is no similar accord on GM. (The Times, 25 June 2003)

Michael Meacher . . . said Mr Blair should not ignore the report. "We don't want GM to be Iraq Mark 2, where the evidence is very slight or even negative, where the great majority is opposed as over Iraq . . . and yet the Government goes ahead in the face of all the evidence," he said. (The Times, 12 July 2003)

Washington has backed away from threats to bring the European Union before the World Trade Organisation over the EU's refusal to allow the sale of geneticallymodified produce. The US's official for agricultural affairs in London, Peter Kurz . . . denied that dropping the plans had anything to do with a desire to smooth relations with Europe before any conflict in Iraq. (Guardian, 21 February 2003)

\section{Summary of newspaper analysis}

The description so far has selected a number of features that emerged during our own analysis of the newspaper corpus. In our interviews and focus-group sessions, we endeavored to ascertain whether these features were indeed salient and important in perceptions of newspaper coverage of GM, either for those with a professional interest in communication of GM issues, or with newspaper readers.

\section{The interviews}

Although our interviewees were not the actual producers of the texts (who were not always available or willing to be interviewed), they were all people involved in the communication and evaluation of issues relating to GM food technology, and were thus well placed to comment on language and communication strategies. They included representatives of antiGM non-governmental organizations (NGOs) (Greenpeace, Friends of the Earth, Genewatch UK, Five Year Freeze) and a biotechnology company (Syngenta); scientists at research institutions (Institute of Food Research, National Institute of Agricultural Botany); a journalist (a leading reporter for a Scottish newspaper); a politician (Chair of the House of Commons Select Committee on Science and Technology); and the dissident scientists Arpad Pusztai and Stanley Ewen, whose controversial research in the 1990s has made them a focus of attention for both proponents and opponents of GM ever since (Robbins, 2005).

The list is not as balanced as we desired. Certain categories of interview proved difficult to arrange during this period, ironically because of the renewed activity around GM. Some government officials, journalists and Monsanto representatives proved particularly elusive. This difficulty may simply reflect the fact that many of the main protagonists were particularly busy. There may also have been an unwillingness by government officials to put views on record during the run-up to the various official announcements made in the second half of 2003. Lack of cooperation by journalists reflected perhaps both professional pressures, and a preference to interview rather than be interviewed. One result of the difficulties we experienced with government, companies and newspapers is that our interviewees represent more anti-GM than pro-GM views. We were able to remedy this imbalance, however, by referring back to the three interviews with representatives of biotechnology companies (including Monsanto) and to the 18 interviews with GM scientists which we conducted as part of an earlier project ${ }^{24}$ (Cook et al., 2004, Cook, 2004, Robbins et al., 2004). 
In what follows, we highlight some points of similarity and contrast between our interviewees (all with specialist interests in the GM debate) and those of our focus groups in their reaction to reporting in the press. Key themes in our analysis of the interview data are participants' perceptions of the debate itself, and the degree of difference between proponents and opponents of GM technology.

\section{Expert cynicism about GM debate in general}

There was a widespread sense of cynicism among interviewees about government decisionmaking and about the level of public debate. Opponents observed that (in the words of one NGO campaigner) "the decision's already been taken." For proponents, opposition was characterized as emerging from the public's ignorance of the technology. As one interviewee said "most of the public do not have the background and the information to make informed decisions." As in the pro-GM press, our pro-GM commentators saw economic, political and historical context as irrelevant to the debate, framing arguments using the language of the deficit model (see Table 3).

Anti-GM commentators, however, were much more likely to invoke a broader context. In the words of one interviewee from an environmentalist NGO: "people are much more in citizen mode when they're not liking GM because of issues like environment, corporate control, changes to agriculture and impacts on farmers." The language that they use to construct their arguments reflects this (see Table 4).

\section{Expert support for GM Nation?}

In contrast to their cynicism about general discussion of GM, our interviewees were surprisingly positive about the GM Nation? debate-perhaps because of their own active role in it. They accepted it as an exercise in the "democratization" of science and technology, designed to restore public trust in government decision-making. Both pro- and anti-GM interviewees, though deeply critical of details, nevertheless believed it to have been a worthwhile exercise. One campaigner said that it addressed people's sense of "democratic deficit" in decision-making. Similarly, a pro-GM commentator from a biotechnology company observed that it was important that "the Government was seen to conduct the process."

Let us now turn to the focus groups, and the degree to which their views coincide with those of our interviewees.

\section{The focus groups}

Six groups were created whose identity might lead them to have views and insights into particular areas of argument in the GM debate, as follows. Potential areas of interest are given in parentheses.

1. birdwatchers (biodiversity)

2. charity workers (ethics and morality)

3. arable farmers (practical consequences for agriculture)

4. undergraduates (long-term effects)

5. parents of young children (health and nutrition)

6. temporary UK residents from poorer $\operatorname{countries}^{25}$ (alleviation of malnutrition).

The first three groups were recruited in the North West of England in the Preston area and the other three were recruited in the South of England, in Reading. Each group met for two 
Table 3. Language used by pro-GM newspapers when referring to arguments for an against GM technology

\begin{tabular}{|c|c|}
\hline Ways of characterizing pro-GM & Ways of characterizing anti-GM \\
\hline Balanced & Polarized \\
\hline Benefits & Highly selective \\
\hline Thoughtful & Scaremongering \\
\hline Calm & Fear \\
\hline Choice & Hostile \\
\hline Truth & Hysteria \\
\hline Evidence & Panic \\
\hline Open-minded & Emotional \\
\hline Open debate & Feverish \\
\hline Objective & Religious \\
\hline Complex & Irrational \\
\hline Facts & Lurid \\
\hline Sound science & Frankenstein \\
\hline Sensible & Frankenfoods \\
\hline Informed & Superweeds \\
\hline Information & Bedevilled \\
\hline Lucid & Demonized \\
\hline Understanding & Danger \\
\hline Reasoned & Genie out of the bottle \\
\hline Rational & Zero risk \\
\hline Strength & $100 \%$ safe \\
\hline Safe & Extreme views \\
\hline Solid & Exaggerate \\
\hline Excellent & Anti-science \\
\hline Level headed & Inappropriate \\
\hline Society wants/Society decides & Lack of realism \\
\hline Public & Does not grasp \\
\hline Peer reviewed & Accusations \\
\hline Precise & Cultural norms \\
\hline Gene insertion & Powerful \\
\hline Tool & Destructive \\
\hline Wish & Activist \\
\hline Impartial & Evangelical \\
\hline Appropriate & Hard core \\
\hline Careful & Hot \\
\hline Experts & Worry \\
\hline Independent & Uninformed \\
\hline Legal & Prejudice \\
\hline Justified & Luddite \\
\hline Rearrangement of genetic material & Immoral \\
\hline Consumer wants/Consumer decides & Cherry-picked \\
\hline Risks minimized & Political agenda \\
\hline Rewards maximized & Unhelpful \\
\hline Functional & Unscientific \\
\hline Nutritional & Inefficient \\
\hline Cutting edge & Ignorant \\
\hline \multirow[t]{4}{*}{ Improved } & Unjustified \\
\hline & Unfounded \\
\hline & Untruth \\
\hline & Michael Meacher \\
\hline
\end{tabular}


Table 4. Language used by anti-GM newspapers when referring to arguments against and in favour of GM technology

\begin{tabular}{|c|c|}
\hline Ways of characterizing anti-GM & Ways of characterizing pro-GM \\
\hline Cautious & Lord Sainsbury \\
\hline Democracy & Tony Blair \\
\hline Fairness & George Bush \\
\hline Farmers & America \\
\hline Testing & Corporations \\
\hline Take time & Monsanto \\
\hline Precautionary principle & Syngenta \\
\hline Trust & Rush \\
\hline Decision making & Imprecise \\
\hline Careful & Artificial \\
\hline Independent & Trigger allergies \\
\hline Context & Frankenstein Foods \\
\hline Engage & Frankencrops \\
\hline Citizens & Risk \\
\hline Questions & Lack of knowledge \\
\hline Listen & Contaminate \\
\hline Impact & Unpredictable \\
\hline Deliberation & Unprecedented \\
\hline Concerns & Unknown \\
\hline Social & Distrust \\
\hline Publics & Bad science \\
\hline Cynical & Arrogant \\
\hline Further research & Assume \\
\hline Politics & Power \\
\hline Economics & Government \\
\hline History & Intensification \\
\hline Participation & Money \\
\hline Consultation & Control \\
\hline Voice & Propaganda \\
\hline Third World & Commercial interests \\
\hline Serious & Patronizing \\
\hline Contested & Sinister \\
\hline Interpret & Unwilling \\
\hline Good science & Superficial \\
\hline Complex & Weak \\
\hline People & Marginalizing opposition \\
\hline Rights & Not substantially equivalent \\
\hline Participative democracy & Sensationalized \\
\hline Wary & Heavy handed \\
\hline Holistic & Unstable \\
\hline More science & Untested \\
\hline Neutral & Side effects \\
\hline Understand & Poorly understood \\
\hline Effects & Biased \\
\hline Long term & Greedy \\
\hline Conscious & Fantastical \\
\hline Traceability & Foist \\
\hline Assess & Farce \\
\hline GM-free & Ban \\
\hline Appal & Bio-genetic cartel \\
\hline Organic & Gloss \\
\hline Certified & Force \\
\hline Consequence & Resistance \\
\hline Judge & Wipe out \\
\hline
\end{tabular}


Table 4. Continued

\begin{tabular}{ll}
\hline Ways of characterizing anti-GM & Ways of characterizing pro-GM \\
\hline Investigate & Unwanted \\
Objective & Potential danger \\
Label & Unexplored \\
Determine & Unforeseeable \\
Health & Indiscriminate \\
Children & Convinced of safety \\
Elderly & Cross-pollinate \\
Infirm & Hurry \\
& Stench \\
& Mendacity \\
& Cover up \\
\hline
\end{tabular}

hours on two occasions making a total of 12 sessions and 24 hours of data. People with special interests (such as involvement in GM research, biotechnology companies, or antiGM campaigns ${ }^{26}$ ) were excluded. The composition of the groups as a whole set out to encompass a range of demographic variables such as age, gender, urban/suburban/rural, and social classifications, North/South of England. Inevitably, however, given the small number of participants $(N=35)$, those variables were not equally distributed among the groups. Among the birdwatchers there was only one young person; all of the farmers were men; one of the charity workers used the opportunity to promote an evangelical view of Christianity; a participant in the student group, originally intended to represent young British adults, was from China, another was an exceptionally loquacious mature student. On the positive side, however, one expected difficulty did not materialize. To our surprise, only two of the 35 participants failed to attend their second session! And all participants engaged enthusiastically with the task.

Focus-group participants reacted to brief written passages about GM. In their first session each group was asked to read three press reports (texts 1, 5 and 6 already cited above), and in preparation for the second session, brief anonymized extracts from two proGM speeches by Prime Minister Tony Blair and by Royal Society President, Lord May both of which had been extensively reported in the press during 2002. (For further discussion of these latter texts and of focus-group reactions to them, neither of which are discussed here, see Cook 2004: 9-19, 126-31.)

\section{Authority, trust and polarization}

One aspect of the participants' own language use deserves mention before moving on to their reaction to other people's language. This is their use of pronouns, a feature which reveals speakers' sense of group boundaries, and their perception of allies and opponents. For example the scientists we interviewed in an earlier project (Cook et al., 2004) used "we" to refer to a perceived community of scientists only, whereas non-scientists linked scientists with politicians as "them." In the current project similar tendencies were revealed through corpus analysis. Focus-group participants showed a marked tendency to use forms of the first person plural- "we," "us" and "our"- to mean something like "ordinary people such as ourselves" and forms of the third person plural ("they," "them," "their") to refer to those perceived to be exercising power undemocratically: the government, corporations, scientists. 
A factor highlighted in our own analysis above-namely the focus upon hypothetical rather than actual developments signified by the use of modal verbs-was commented on by the participants. This suggests that-at least in circumstances where the text is focused upon intensely and discussed at great length - sensitivity to linguistic nuance is high. (The symbol * indicates a new speaker.)

It could help endangered birds. They haven't proved that it does. (Farmers)

It just says "could" * Yes I just spotted that * Which is very ambiguous, isn't it? (Charity Workers)

Well another thing that's in there. It says it could help. It doesn't say it will. So therefore it's not necessarily scientifically proven either. (Parents)

It's not saying modified crops will help endangered birds i.e. lapwings, it just says "such as" and it says it can kill weeds it doesn't say it does kill weeds. So the terminology' s very vague. (Undergraduates)

The most salient factor in participants' orientation towards the texts was not linguistic as such, however, but concerned the identity of the speaker or the source. This was particularly evident in reactions to the sentence "The study was funded by GM giant Monsanto" (text 5) and the references to Lord Sainsbury (text 6). This was part of a general sensitivity to inexplicit connection between sentences, and demonstrates inferencing in the light of prior political judgment which, as we have indicated above, seems to be assumed by the writers of press reports. In this sense names of organizations and individuals act as frames, to which participants respond critically. The extracts below (grouped under the headings "scientists," "politicians," "government" and "corporations") typify more generally reactions to sources of information as reported in the press, and their trustworthiness, illustrating the erosion of the public's faith in social institutions. Beck (1992) identified this breakdown of trust as a key aspect of living in the risk society (cf. Robbins et al., 2004). Giddens (1991) also observed a similar process, noting that social perceptions of institutional failure contribute to enhanced reflexivity and self monitoring. As such, most focus-group participants came to the conclusion that they could only trust themselves; that is, their own understanding of where the "truth" in the various storylines about GM food actually lay.

\section{On scientists}

* Yes maybe we trust them [scientists] now but in the future people will say they're sorry, they made a mistake so.

* Yes it's possible, because science makes mistakes doesn't it.

(Undergraduates)

* That's why there's a debate to my mind. The problem with GM is nobody knows anything about it.

* Well scientists don't know do they-the answer-the long term answer.

* They won't have anything to do with it; they'll only let you know what they want you to know.

* Well yes but ...

* No matter what they develop, I mean: who cares? Or whatever-you know? 
* It's a free country as long as you do as you're told.

(Farmers)

\section{On politicians}

I wish I knew a bit more about it really I don't think it's I don't want to hear it from the politicians necessarily either you know maybe an independent study or two or three even but not I don't want Tony Blair telling me about it I'm not going to trust him. (Undergraduates)

* What I feel is Tony Blair is for genetic modification that's the biggest argument.

* It certainly is, yes definitely.

* I mean you can't trust a word he says.

* No you can't.

* Well any politician-now can you? They're all the same.

* Well he's worse than a lot of them.

(Birdwatchers)

On the government

And I just don't trust the Government and the Department of Environment etc. to supervise it properly because my husband used to keep bees. And he knows how far a bee will travel searching for, you know, for nectar and the "powers that be" said "oh a GM crop in such an area cannot possibly cross pollinate, you know, because we've sterilized the area around it". And I read a few months ago that it had cross pollinated already, because bees will fly 3 miles and why don't those idiots at DEFRA [Department for Environment, Food and Rural Affairs] know that, you know? And that's what worries me. I just feel it's all being driven by big business. (Birdwatchers)

\section{On corporations}

But they're only pawns of whatever anyway. I mean huge conglomerates like pharmaceutical companies and so forth have so much vested interest in their finances that's their predominance of thinking. So where do you find someone that you can really trust? I would personally rather listen to someone in the agricultural field that has been involved in it for their lives and has seen the natural relevance of what they've done-whether it's putting specific manure onto a particular plot that produces a better yield or whatever. That, to me, would give me more confidence in believing what they were saying than someone that's trying to achieve an ulterior motive. (Charity Workers)

... This is all about money; it's all about money. It's about getting more food. They have enough to feed the people. It's just all commercial rubbish; they just want to make more money. (Temporary Residents)

It all sounds very nice the genetically modifying of foods to increase nutrition and beneficial values and all this, but from a point of view of increasing yield what's the 
point? The western world's awash with food, we're paid to leave ground fallow. What's the whole end produce if it's not being driven by multi-nationals from a profit basis? (Farmers)

\section{Public frames: GM, the power elite and the war in Iraq}

Participants in the focus groups appeared to make sense of GM by reconfiguring media framing devices referring to broader historical and cultural themes. They viewed GM through the lens of current events, and drew broad parallels between the interests and practices of key institutional actors. In this, they appeared to share the view of C. Wright Mills, expressed half a century ago, that a "power elite" consisting of military, economic and political leaders, have oligopolistic control over foreign and domestic policy decisions (Mills, 1956), and regard GM as symbolic of this domination. Notably, respondents in the birdwatchers group talked of ripping up GM crops as a way of striking out against the government, corporations, the United States, and the war in Iraq.

The following quotations show how this mixing takes place, and the ways a skeptical public pick up and reverse the meanings of the emotive epithets identified in our newspaper analysis above. They turn the science frame-the argument that "GM is based on sound science, opposition is based on ignorance" — on its head. Like Hester Prynne, the main character in Nathaniel Hawthorne's novel The Scarlet Letter who embroiders the letter "A" (representing "adulterer") that she is forced to wear, thus turning it from a punishment into a badge of honor (representing her free spiritedness), some participants converted arguments that attempt to brand them "emotional," "fearful," "biased" and "unintelligent" into strengths.

Here, for example, the speaker turns the "Luddite" invective into an anti-capitalist call to action, and also voices the sense of powerlessness that underpins this (our emphasis throughout the following examples):

* I'm Luddite enough that if I had been invited to take part in an illegal activity of pulling up crops I would

* trample on it

* Yes I would do that

* Yes

* If I had sufficient knowledge to do that I would. But I don't think it is a particularly political decision. I think we are driven by the Government, we are driven by the multinationals. I mean you've got to look at the American situation, where the Americans have let contracts to rebuild in Iraq and those are companies which have funded the presidential election campaign. Donald Rumsfeld's company has got a walloping great contract out of that. So it's not clear cut at all.

(Birdwatchers)

Here a speaker challenges the characterization of opposition as irrational:

It's rather condescending to say we're all emotional and irrational. I mean, we all have points of view and . . . just because we don't agree we're not emotional and irrational. (Charity Workers)

Another speaker parodies the language of the science frame, which he/she sees as a disingenuous cover for the political-economic interests of George Bush and the US, which 
are to shift blame for famine in Africa and facilitate export of GM, again wrapped up in dubious reasons for the invasion of Iraq.

* Mr George Bush I hate him. I hate the man so again I'm going to be biased here. He's always going to tell everybody what to do. If there were a position of being king of the world he would definitely want to fill that one.

$*$ He is ...

* Yes, he's not in my book. But he's always trying to tell people what to do. He thinks he's Flash Gordon and he can tell people what to do. I don't think he's interested in biotech in Africa. I think he's interested in his crops not being sold in Europe because the European governments are opposing GM and then that destroys exports from the US. My criticisms are "unfounded" as Mr George Bush says but I suppose that's the reason behind it, because if they [Americans] are basically GM and they are using lots of GM it's not the poor African countries that are dying because of famine that he's interested in or he's worried about. He's worried about his own crops not being sold in Europe, and then it's just the use of words "they're responsible for famine"-so let it stay in your head. And the reasons behind George Bush's movements and strategies are so dirty that I can't trust a word he says. I'm "having unscientific fears" you know. Who does he think he is?

\section{(Temporary Residents)}

This resistance is further mixed with the links between GM and Iraq, documented in our newspaper corpus, and amplified. In the following extracts, participants, through some memorable word play, engage with the pro-GM science frame that opposition to GM is "irrational" and turn that back on Iraq and weapons of mass destruction (WMD).

* It's rational to have evidence but [Tony Blair] didn't give us proof that Iraq had weapons of mass destruction so I think ...

* Yes, maybe he always tells lies ...

(Undergraduates)

* Well we can't really discuss it properly because we don't know everything . . . we only know what we've been told by the Government . . . I mean the cat's been let out of the bag now hasn't it? Because we now realize that we were not told the truth about the war and those chickens are coming home to roost and I doubt that we'll ever know the full story.

* Genetically modified chickens

* Hey we're going to end up with our own weapons of mass destruction here and they're going to be sort of modified chicks or something.

(Birdwatchers)

* I think the politicians are afraid to speak their mind and tell the truth as they see it.

* If they're telling us the truth, they get in trouble for it.

* Well with that we come back to the business of the . .

* WMD

* Yes

* “Words of Mass Deception" 
* Yes that's it ...

* What was that?

* "Words of Mass Deception"

* Yes

* That perhaps the politicians have bitten off more than they can chew.

(Birdwatchers)

These focus-group data show how the public engage with arguments from particular sources. They reveal something of the politics of authority. Wynne (2001) has observed that non-experts "triangulate" the information they receive from the establishment when making decisions about genetically modified organisms. More than this, people also synthesize and reconfigure storylines to create new narratives, often with self aware and ironic humor, as illustrated when focus-group speakers turn the "Luddite" criticism into a strength, or when birdwatchers talk about genetically modified chickens being a weapon of mass destruction.

\section{Conclusions}

This study, employing a combined linguistic and sociological methodology, confirms existing findings on the nature of GM discourse. The linguistic construction of articles points to the subtle ways in which stories are framed allowing readers to make implicit connections between different cultural themes and events, such as globalization and the war in Iraq. Possible rather than actual developments were reported, sources and authorities were cited, leading readers to an indirect assessment of the argument, and facts were stated without explicit connections to previous text, leaving relationships to be inferred. Allusions to sources, such as Tony Blair, were also used to bolster or undermine credibility, and metaphors having associations with militaristic conflict, such as "war," "battle," and "attack" were frequently employed.

Experts we interviewed on "the GM debate" tended to understand this phrase more narrowly as the national GM debate organized by the UK government in 2003-4 investigating public attitudes to biotechnology, rather than the GM question in general. They expressed frustration that the debate process had become bound up in wider political contests. Focus-group participants, who were largely unaware that such a debate was going on, synthesized contemporary cultural and political narratives to understand and articulate positions on biotechnology. In examining texts, they formed views based on the identity of the speaker or source, and these references, such as to Monsanto and Lord Sainsbury, acted as framing devices. Participants also made explicit some of the buried cultural associations in newspaper articles, linking specific GM crop innovations and the biotechnology revolution to more historically insightful narratives about power relations and the trustworthiness of key institutions, including government, industry, science as well as the media itself, while unpicking the dubious justifications for the Iraq campaign. In so doing, they employed a knowing and ironic style of word play that lampooned and demythologized the key players involved. 


\section{Acknowledgement}

The research reported in this article was funded by a grant from the Economic and Social Research Council (ESRC) ("The Discourse of the GM Food Debate," ESRC RES000-22-0132).

\section{Endnotes}

1 “The Discourse of the GM Food Debate," ESRC RES-000-22-0132.

2 Including citizens' juries organized by local councils.

3 "GM Crops: Effects on Farmland Wildlife" (2003) [online] http://www.defra.gov.uk/environment/gm/fse/ results/fse-summary.pdf (accessed 10 December 2003).

4 Prime Minister's Strategy Unit (2003) "Weighing up the Costs and Benefits of GM Crops" [online] http:/ /www.strategy.gov.uk/files/pdf/gm_crop_report.pdf (accessed 20 February 2004).

5 GM Science Review Panel (2003) GM Science Review: First Report, pp 129-31 [online] http:/ /www.gmsciencedebate.org.uk/report/default.htmffirst (accessed 20 February 2004).

6 Functional linguistics is premised on the belief that "the phonological, grammatical and semantic structures of a language are determined by the functions they have to perform in the societies in which they operate" (Lyons, 1977: 224). It is a formative influence on applied linguistics (Cook, 2003), the discipline concerned with "the theoretical and empirical investigation of real-world problems in which language is a central issue" (Brumfit, 1995: 27).

7 Framing has been defined as the "central, organizing idea or theme of a message" (Gamson and Modigliani, 1989: 3), while "framing devices" have been conceptualized as implements used by the media to convey information to the public. According to Gamson and Modigliani, framing devices must have "narrative fidelity" - or resonate with larger cultural issues - in order to give meaning. Entman went further in arguing that words themselves can act as frames, which can encourage moral or normative associations in the mind of the reader in order to "form a way of reasoning about a matter that is familiar to audiences from other cultural experiences" (Entman, 1991: 11).

8 The program we used is Wordsmith Tools.

9 With Atlas.ti (a software for qualitative analysis allowing a constant comparative approach).

10 There are a number of valid reservations about corpus analysis in general (Cook, 1998) and specific issues might also have arisen, had we not taken into consideration the nature of our own data. It was important to be aware that certain words occurred frequently in our transcripts simply because they were in passages presented to interviewees or focus groups, or because we asked questions about them, or because they were in our own utterances as interviewers and moderators.

11 Under the terms of the University of Reading's licence from the Newspaper Licensing Authority.

12 Retrospectively, it was the Independent rather than the Guardian which was the more actively anti-GM broadsheet-style newspaper during this period.

13 These terms refer to a generally accepted distinction in linguistics and semiotics (Levinson, 1983: 1; Morris, 1938: 86) between syntactics, the study of "the formal relation of signs to each other" (i.e. their forms), semantics, the study of "the relations of signs to the objects to which they are applicable" (i.e. their meanings) and pragmatics, the study of "the relation of signs to interpreters" (i.e. their use).

14 For further discussion of this tendency in pro-GM arguments, see Cook et al. (2004), Cook (2004), and Pieri (2004, 2005).

15 "Luddite" in public debate has come to signify dim-witted, irrational, bigoted, violent, and badly organized opposition to all technology. Historically, the actual Luddites were very different. For discussion see Thompson (1963), Sale (1995), and (with reference to the use of the term in pro-GM arguments) Cook (2004: 105-7).

16 Guardian, 19 November 2002.

17 The Times, 20 June 2003.

18 Guardian, 17 May 2003.

19 Daily Mail, 3 July 2003.

20 Guardian, 29 November 2002.

21 The Times, 22 July 2003.

22 Report by the National Institute of Agricultural Botany, quoted in the Guardian, 3 January 2003.

23 Guardian, 4 June 2003.

24 "The Presentation of GM Crop Research to Non-Specialists: A Case Study," ESRCR/000/22/3725, November 2001-November 2002. This earlier project was a case-study of the GM debate in a single higher-education 
institution engaged in GM research, and one particular discourse community within that institution (GM plant scientists), see Cook et al. (2004), Cook (2004).

25 From countries listed as having "medium" or "low" human development in the UN Development Programme's Human Development Index (UNDP, 2002). However, one of our informants was from Argentina, a country now having "high human development," but still suffering significant inequality, and commonly considered to be part of the "third world" (Sklair and Robbins, 2002).

26 The fact that the Royal Society for the Protection of Birds is opposed to commercial GM agriculture was not taken to indicate that members of the birdwatchers' group are actively anti-GM.

\section{References}

AEBC (Agriculture and Environment Biotechnology Commission) (2001) Crops on Trial: a Report by the AEBC. London: AEBC

Beck, U. (1992) Risk Society. London: Sage.

Becker, H. (1998) Tricks of the Trade: How to Think about your Research While You're Doing It. Chicago: Chicago University Press.

BEPCAG (Biotechnology and the European Public Concerted Action Group) (1997) "Europe Ambivalent on Biotechnology," Nature 387: 845-7.

Berger, P. and Luckmann, T. (1967) The Social Construction of Reality. Harmondsworth: Penguin.

Brown, G. and Yule, G. (1983) Discourse Analysis. Cambridge: Cambridge University Press.

Brumfit, C.J. (1995) “Teacher Professionalism and Research,” in G. Cook and B. Seidlhofer (eds) Principle and Practice in Applied Linguistics, pp., 27-43. Oxford: Oxford University Press.

Burton, M., Rigby, D., Young, T. and James, S. (2001) "Consumer Attitudes to Genetically Modified Organisms in Food in the UK," European Review of Agricultural Economics 28(4): 479-98.

Carson, R. (1999 [1962]) Silent Spring. Harmondsworth: Penguin.

Cook, G. (1998) "The Uses of Reality: A Reply to Ronald Carter," English Language Teaching Journal 52(1): 57-64. Reprinted in D. Hall and A. Hewings (eds) (2001) Innovation in English Language Teaching: A Reader, pp. 64-71. London: Routledge.

Cook, G. (2003) Applied Linguistics. Oxford: Oxford University Press.

Cook, G. (2004) Genetically Modified Language. London: Routledge

Cook, G., Pieri, E. and Robbins, P.T. (2004) "'The Scientists Think and the Public Feels': Expert Perceptions of the Discourse of GM Food," Discourse and Society 15(4): 433-49.

Davidson, A., Barns, I. and Schibeci, R. (1997) "Problematic Publics: A Critical Review of Surveys of Public Attitudes to Biotechnology," Science, Technology and Human Values 22(3): 317-48.

Entman, R.M. (1991) "Framing U.S. Coverage of International News: Contrasts in Narratives of the KAL and Iran Air Incidents," Journal of Communication 41(4): 6-27.

Fairclough, N. and Wodak, R. (1997) "Critical Discourse Analysis," in T. van Dijk (ed.) Discourse as Social Interaction, pp. 258-9. London: SAGE.

Finucane, M.L. (2002) "Mad Cows, Mad Corn and Mad Communities: The Role of Socio-cultural Factors in the Perceived Risk of Genetically-modified Food," Proceedings of The Nutrition Society 61(1): 31-7.

Gamson, W. and Modigliani, A. (1989) "Media Discourse and Public Opinion on Nuclear Power: A Constructionist Approach," American Journal of Sociology 95: 1-38.

Gaskell, G. and Bauer, M.W., eds (2001) Biotechnology 1996-2000: The Years of Controversy. London: Science Museum Press and East Lansing, MI: Michigan State University Press.

Gee, P. (1999) An Introduction to Discourse Analysis: Theory and Method. London: Routledge.

Giddens, A. (1991) The Consequences of Modernity. Cambridge: Polity.

Gill, R. (2000) "Discourse Analysis," in M. Bauer and G. Gaskell (eds) Qualitative Researching with Text, Image and Sound, pp. 172-90. London: SAGE.

Glaser, B.G. and Strauss, A.L. (1967) The Discovery of Grounded Theory: Strategies for Qualitative Research. Chicago: Aldine Publishing.

Gregory, J. and Miller, S. (1998) Science in Public: Communication, Culture, and Credibility. Cambridge, MA: Perseus.

Hedgecoe, A. (2004) The Politics of Personalised Medicine. Cambridge: Cambridge University Press.

Heller, R. (2003) GM Nation? The Findings of the Public Debate [online]. London: HMSO. Available: http:/ /www.aebc.gov.uk/aebc/reports/gm_nation_report_final.pdf (accessed 20 November 2003).

Hornig Priest, S. (2001) A Grain of Truth: the Media, the Public and Biotechnology. Lanham, MD: Rowman and Littlefield. 
Hunston, S. (2002) Corpora in Applied Linguistics. Cambridge: Cambridge University Press.

INRA (2002) "The Europeans and Biotechnology," EuroBarometer report by INRA (Europe). ECOSA, for EU. Brussels: DG Research.

Jucker, A.H. (1992) Social Stylistics: Syntactic Variation in British Newspapers. Berlin and New York: Mouton de Gruyter.

Lakoff, G. and Johnson, M. (1980) Metaphors We Live By. London and Chicago: University of Chicago Press.

Lambrecht, B. (2001) Dinner at the New Gene Cafe: How Genetic Engineering Is Changing What We Eat, How We Live, and the Global Politics of Food. New York: St. Martin's Press.

Levinson, S.C. (1983) Pragmatics. Cambridge: Cambridge University Press.

Louw, B. (1993) "Irony in the Text or Insincerity in the Writer? The Diagnostic Potential of Semantic Prosodies," in M. Baker, G. Francis and E. Tognini-Bonelli (eds) Text and Technology, pp. 157-76. Amsterdam: Benjamins.

Lyons, J. (1977) Semantics, two vols. Cambridge: Cambridge University Press.

Marris, C., Wynne, B., Simmons, P. and Weldon, S. (2001) Final Report of the PABE [Public Attitudes to Biotechnology in Europe] Research Project. Funded by the Commission of European Communities. Available: http://www.lancs.ac.uk/depts/ieppp/pabe/docs/pabe_finalreport.doc

Mills, C.W. (1956) The Power Elite. Oxford: Oxford University Press.

Morris, C.W. (1938) "Foundation of the Theory of Signs," in O. Neurath, R. Carnap and C. Morris (eds) International Encyclopedia of Unified Science, pp. 77-138. Chicago: University of Chicago Press.

Nerlich, B. (2003) "Tracking the Metaphor Silent Spring in British Environmental Discourse: Towards an Evolutionary Ecology of Metaphor," Metaphorik [online]. Available: http://www.metaphorik.de/ 04/nerlich.pdf

O'Halloran, K. (2003) Critical Discourse Analysis and Language Cognition. Edinburgh: Edinburgh University Press.

Pardo, R., Midden, C. and Miller, J.D. (2002) “Attitudes toward Biotechnology in the European Union,” Journal of Biotechnology 98: 9-24.

Pieri, E. (2004) "The GM Debate and Public Participation," Fare Choice (The Quarterly Newsletter of the Scottish Community Diet Project) Issue 28(Summer): 4.

Pieri, E. (2005) “The GM Nation Debate: Participatory Decision-Making?,” in J.D. Wulfhorst and A.K. Haugestad (eds) Building Sustainable Communities: Ecological Justice and Global Citizenship, forthcoming. Amsterdam and New York: Rodopi.

Pinstrup-Anderson, P. and Schioler, E. (2001) Seeds of Contention: World Hunger and the Global Controversy over GM Crops. Baltimore, MD and London: John Hopkins University Press.

Robbins, P.T. (2003) "Transnational Corporations and the Discourse of Water Privatization," Journal of International Development 15: 1073-82.

Robbins, P.T. (2005) "The Social Construction of GM Safety Scientists' Research: Narratives and Boundaries," Paper presented at the American Sociological Association Annual Meeting, Philadelphia.

Robbins, P.T., Pieri, E. and Cook, G. (2004) "GM Scientists and the Politics of the Risk Society," in A.K. Haugestad and J.D. Wulfhorst (eds) Future as Fairness: Ecological Justice \& Global Citizenship, pp. 85-105. Amsterdam and New York: Rodopi.

Sale, K. (1995) Rebels Against the Future. London: Addison Wesley.

Scott, A. (2001) "Technological Risk, Scientific Advice and Public 'Education': Groping for an Adequate Language in the Case of GM Foods," Environmental Education Research 7: 129-39.

Scott, A., Stephens, C. and Bullock, S. (1999) The Politics of GM Food: Risk, Science and Public Trust. Global Environmental Change Programme (GECP) of the Economic and Social Research Council: 24. Special Briefing No. 5. Brighton: GECP.

Sklair, L. and Robbins, P.T. (2002) "Global Capitalism and Major Corporations from the Third World," Third World Quarterly 23(1): 81-100.

Smith, J.M. (2003) Seeds of Deception. Fairfield, IA: Yes Books.

Sontag, S. (1988) AIDS and its Metaphors. Harmondsworth: Penguin.

Strauss, A. and Corbin, J. (1990) Basics of Qualitative Research: Grounded Theory Procedures and Techniques. Thousand Oaks, CA: Sage.

Stubbs, M. (1983) Discourse Analysis. Oxford: Blackwell.

Stubbs, M. (1996) Text and Corpus Analysis. Oxford: Blackwell.

Thompson, E.P. (1963) The Making of the English Working Class. London: Vintage.

UNDP (United Nations Development Programme) (2002) Human Development Report. Oxford: Oxford University Press. 
Wield, D. and Carr, S. (2002) "Trading Up Standards? Trans-Atlantic Governance of GM Crops," ESRC R000239460. Swindon: Economic and Social Research Council.

Wynne, B. (2001) "Risk and Environment: Expert Cultures of Risk and Ethics on GMOs," Science as Culture 10(4): 445-81.

\section{Authors}

Guy Cook is Professor of Language and Education at the Open University in England. His most recent books are Language Play, Language Learning (Oxford University Press, 2000), The Discourse of Advertising (Routledge, second edition 2001) Applied Linguistics (Oxford University Press, 2003) and Genetically Modified Language (Routledge, 2004). He is coeditor of the journal Applied Linguistics. Correspondence: Guy Cook, Professor of Language and Education, Faculty of Language and Education, Briggs Building, The Open University, Milton Keynes MK7 6AA, UK, e-mail: g.cook@open.ac.uk

Peter T. Robbins is Lecturer in Development Studies at the Open University, and is a member of academic staff at the ESRC Centre for the Study of Innovation in Genomics (INNOGEN), co-directed by the Open University and the University of Edinburgh. He is author of Greening the Corporation (Earthscan, 2001), and Sociology of Development (University of London Press, 2001). His research and publications explore the politics of major corporations and technologies from a global perspective.

Elisa Pieri is Research Associate at the ESRC Centre for Economic and Social Aspects of Genomics, IEPPP, University of Lancaster. She researches public engagement in relation to the ethical, legal and social dimensions of genetics regarding human health and personalized medicine. Her main research interests are critical discourse analysis, language and power and public engagement. 